\title{
The potential impact of compositional changes in farmed fish on its health-giving properties: is it time to reconsider current dietary recommendations?
}

\author{
Baukje de Roos ${ }^{1, *}$, Alan A Sneddon ${ }^{1}$, Matthew Sprague ${ }^{2}$, Graham W Horgan ${ }^{3}$ and \\ Ingeborg A Brouwer ${ }^{4}$ \\ ${ }^{1}$ Rowett Institute, University of Aberdeen, Foresterhill, Aberdeen AB25 2ZD, UK: ${ }^{2}$ Institute of Aquaculture, University \\ of Stirling, Stirling, UK: ${ }^{3}$ Biomathematics and Statistics Scotland, Aberdeen, UK: ${ }^{4}$ Health Sciences, Vrije Universiteit \\ Amsterdam, Amsterdam, The Netherlands
}

Submitted 8 November 2016: Final revision received 17 March 2017: Accepted 27 March 2017: First published online 24 May 2017

\begin{abstract}
Assessment of national dietary guidelines in a number of European countries reveals that some are based on cohort studies, focusing on total seafood consumption, while others are based on the content of EPA and DHA, distinguishing between oily and other fish. The mean actual intake of fish in most countries is around or below the recommended intake, with differences in intake of fish being present between sex and age groups. Many people do not reach the national recommendation for total fish intake. Dietary recommendations for fish and EPA/DHA are based mainly on data collected more than 10 years ago. However, methods of farmed fish production have changed considerably since then. The actual content of EPA and DHA in farmed salmon has nearly halved as the traditional finite marine ingredients fish meal and fish oil in salmon diets have been replaced with sustainable alternatives of terrestrial origin. As farmed salmon is an important source of EPA and DHA in many Western countries, our intake of these fatty acids is likely to have decreased. In addition, levels of vitamin D and Se are also found to have declined in farmed fish in the past decade. Significant changes in the EPA and DHA, vitamin D and Se content of farmed fish means that average intakes of these nutrients in Western populations are probably lower than before. This may have consequences for the health-giving properties of fish as well as future dietary recommendations for fish intake.
\end{abstract}

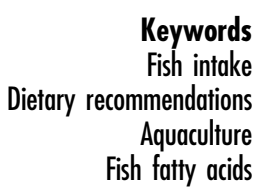

\section{Fish supply and trends in fish production}

Fish and fishery products play an important role in the provision of dietary needs for long-chain PUFA (LC $n-3$ PUFA), protein, vitamins and minerals ${ }^{(1)}$. Fish are a critical food source for many local communities in Africa and Asia where capture fisheries and aquaculture may provide people with between $50 \%$ and $60 \%$ of their average per capita intake of animal protein ${ }^{(2)}$. In the past five decades, the total supply of fish for food consumption has increased at an annual rate of $3 \cdot 2 \%$, while the world population has increased by $1.6 \%$ per annum in the same period. The relative increase in supply of fish for consumption is mostly due to population growth, rising incomes, urbanisation and a strong expansion of global production and distribution of fish products ${ }^{(3)}$. A recent International Model for Policy Analysis of Agricultural commodities and Trade (IMPACT) model projected that fish production is expected to grow by nearly $24 \%$ between 2010 and 2030, and the world population is projected to grow at just over $20 \%$ during the same period, ensuring that increased fish consumption can be managed ${ }^{(4)}$. However, the increase in production cannot only be delivered by wild capture fisheries. Indeed, the proportion of assessed marine fish stocks fished within biologically sustainable levels declined from $90 \%$ in 1974 to $71 \%$ in 2011 , with $29 \%$ of 
fish stocks being overfished ${ }^{(3)}$. Aquaculture has the potential to take the pressure off wild fish stocks while meeting the dietary needs of the population for LC $n-3$ PUFA and other key nutrients such as vitamin D. In 2014, the aquaculture sector's contribution to the supply of fish for human consumption overtook that of wild-caught fish for the first time, compared with a contribution from aquaculture of just over 13\% in 1990 and just over $25 \%$ in 2000. This highlights the global trend that aquaculture development is gaining importance in the total fish supply $^{(3)}$.

The significant increase in production of farmed fish has led to an increase in aquaculture's share of global fish meal and fish oil consumption. However, at the same time, there has been a decrease in the overall use of fish meal and fish oil in this sector in response to higher commodity prices, improvements in aquaculture feed efficiencies, reduced feed conversion ratios and substitution of non-fish ingredients into formulated feeds. Indeed, various plant- and animal-based alternatives to fish meal and fish oil are now being used in or are available for industrial aquafeeds, depending on relative prices and consumer acceptance ${ }^{(5)}$. However, use of such aquafeeds has led to a significant reduction in the content of LC $n-3$ PUFA, especially known to have happened in farmed salmon ${ }^{(6,7)}$, and may affect the content of other nutrients such as micronutrients and vitamins.

The aim of the present report is to evaluate how changes in methods of farmed fish production may affect the health-giving properties of fish and how this relates to meaningful dietary recommendations.

\section{Comparing dietary intakes and dietary recommendations}

Dietary recommendations for fish consumption vary considerably between several European countries, with the lowest recommendation in the Netherlands, being 1 portion of fish per week, and the highest recommendation in Spain, being 2-4 portions of fish per week (Table 1). Dietary recommendations for fish intake in the Netherlands and Spain are based on results of cohort studies described in two recent meta-analyses, confirming that compared with very low fish intake (i.e. $<1$ serving/ month), low fish intake (1 serving/week) reduces risk for CHD and stroke by $16 \%$ and $14 \%$, respectively, and moderate fish intake (2-4 servings/week) reduces risk for CHD and stroke by $21 \%$ and $9 \%$, respectively ${ }^{(8,9)}$. The UK, however, still bases its recommendations on the content of the main fish fatty acids EPA and DHA, which are believed to be mainly responsible for the beneficial effects of fish consumption on cardiovascular health ${ }^{(10)}$ (Table 1). The recommendations in Norway and Germany have been established by taking into account both fish intake and intake of EPA and DHA. Interestingly, the Dutch recommendation was recently lowered from $450 \mathrm{mg}$ EPA plus DHA daily, which translated into 'eating fish twice a week, of which one should be fatty fish', to 'eating fish once a week, preferably fatty fish'. This new recommendation is based mainly on cohort studies and makes no reference to intake of EPA plus DHA ${ }^{(11)}$. The Netherlands, Germany and the UK are among an increasing number of countries that take the ecological perspective into account in their recommendation ${ }^{(12,13)}$.

Table 1 Current dietary recommendations for intake of fish and fish fatty acids (EPA/DHA) in Germany, the Netherlands, Norway, Spain and the UK

\begin{tabular}{|c|c|c|c|}
\hline $\begin{array}{l}\text { Country/ } \\
\text { region }\end{array}$ & Organisation & Food-based recommendation & Background of the recommendation \\
\hline Germany & $\begin{array}{l}\text { German Nutrition } \\
\text { Society }\end{array}$ & $\begin{array}{l}\text { 'Eat fish once to twice a week. Choose fish } \\
\text { from recognised sustainable sources' }\end{array}$ & $\begin{array}{l}\text { The evidence for the primary prevention of CHD } \\
\text { through the intake of long-chain } n-3 \text { fatty acids is } \\
\text { judged as probable (based on cohort studies). } \\
\text { This applies to an intake of at least up to } 250 \mathrm{mg} \\
\text { EPA plus DHA daily }\end{array}$ \\
\hline Netherlands & Dutch Health Council & 'Eat fish once a week, preferably fatty fish' & $\begin{array}{l}\text { Based on strong evidence from cohort studies }{ }^{(8,41)} \text {, } \\
\text { showing that fish consumption } \geq \text { once/week is } \\
\text { associated with a } 15 \% \text { lower risk of coronary } \\
\text { death and a } 10 \% \text { lower risk of stroke compared } \\
\text { with fish consumption } \leq \text { once/month }\end{array}$ \\
\hline Norway & $\begin{array}{l}\text { Norwegian Nutrition } \\
\text { Council }\end{array}$ & $\begin{array}{l}\text { 'Eat fish for dinner two to three times a week. } \\
\text { Fish is also a great filling in sandwiches' }\end{array}$ & $\begin{array}{l}\text { The recommendation of fish in Norway is based } \\
\text { on studies on content of fish fatty acids } \\
\text { (EPA + DHA), however studies on total fish intake } \\
\text { have also been taken into consideration }\end{array}$ \\
\hline Spain & $\begin{array}{l}\text { Agencia Española de } \\
\text { Consumo, Seguridad } \\
\text { Alimentaria y Nutrición }\end{array}$ & 'Eat fish two to four times a week' & $\begin{array}{l}\text { The recommendation is based on analysis of cohort } \\
\text { studies conducted in Mediterranean countries } \\
\text { assessing the effect of fish and shellfish } \\
\text { consumption on total and CVD mortality }\end{array}$ \\
\hline $\mathrm{UK}^{*}$ & $\begin{array}{l}\text { Scientific Advisory } \\
\text { Committee on } \\
\text { Nutrition }\end{array}$ & $\begin{array}{l}\text { 'Two portions of fish per week of which one } \\
\text { should be oily. This will provide } 450 \mathrm{mg} \text { of } \\
\text { the very long chain } n-3 \text { fatty acids per day' }\end{array}$ & $\begin{array}{l}\text { Reinforcement of previous dietary guidelines issued } \\
\text { in 1994. Based on an intake of } 2-3 \mathrm{~g} \text { EPA plus } \\
\text { DHA weekly }\end{array}$ \\
\hline
\end{tabular}

*The Scottish Dietary Goal is consumption of one oily fish per week, based on its content of EPA and DHA. This advice is issued by the Food Standards Scotland. 


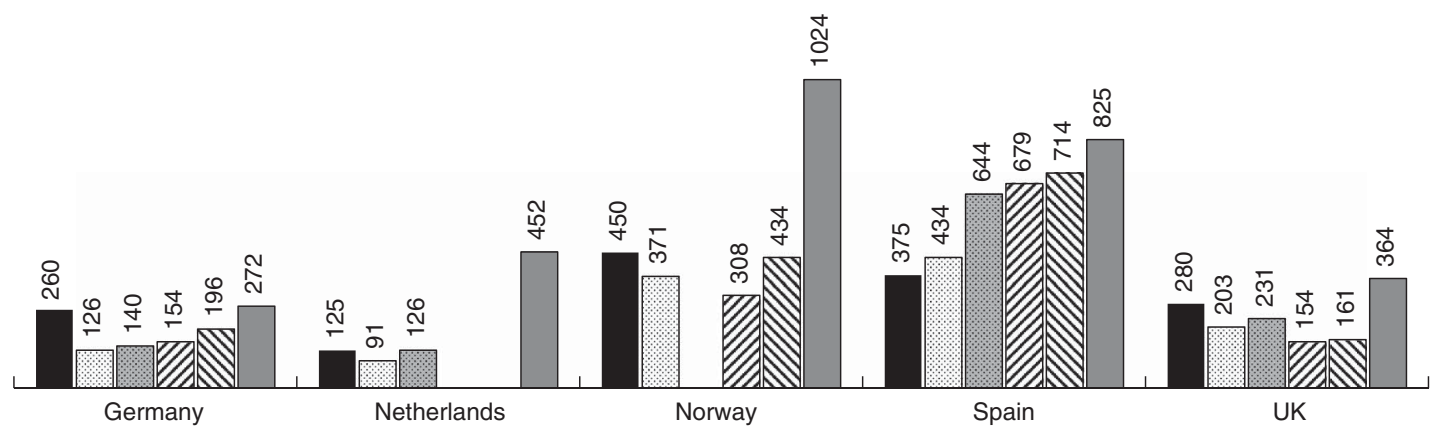

Fig. 1 Recommendations $v$. average intake (g/week) of total fish in Germany, the Netherlands, Norway, Spain and the UK: $\mathbf{\square}$, national recommendations; 8 , intake females (EPIC); $\mathrm{O}$, intake males (EPIC); $\square$, intake females (national assessment); $\boldsymbol{\nabla}$, intake males (national assessment); $\square$, food balance sheets. Calculations from number of portions to grams per week were made with nationally identified portion sizes (150/200 g for women/men in Germany, $125 \mathrm{~g}$ in the Netherlands, $150 \mathrm{~g}$ in Norway, $125 \mathrm{~g}$ in Spain and $140 \mathrm{~g}$ in the UK); EPIC, European Prospective Investigation into Cancer and Nutrition

Interestingly, countries with the highest national recommendations, such as Spain and Norway, also have the highest intake of fish (Fig. 1). Many current food-based dietary guidelines are country-specific and are likely to reflect national dietary habits ${ }^{(14)}$. Therefore, countries with a tradition to eat marine food, perhaps due to their geography, may include more portions of fish in their food-based dietary guidelines than countries without this tradition. Table 2 compares the intake of total fish across a number of northern, mid- and south landlocked and coastal European countries with varying levels of fish consumption, using three different approaches: (i) fish intake as measured by a standardised computerised $24 \mathrm{~h}$ recall interview in a number of European countries participating in the European Prospective Investigation into Cancer and Nutrition (EPIC) cohort between 1992 and $2000^{(15)}$; (ii) FAO data for apparent consumption of fish based on food balance sheets ${ }^{(16)}$; and (iii) fish intake as measured in more recent national assessments of dietary intake of fish ${ }^{(17-21)}$. The lowest fish consumption was found in Germany and the Netherlands, whereas the highest consumption was found in Spain and Norway. Most studies reported higher intakes of fish in elderly subjects (aged 65+ years) compared with younger subjects, and higher intakes in men compared with women $^{(15,17-21)}$ (Table 2). The positive relationship between age and frequency of seafood consumption has previously been found to be mediated by sensory appeal (attitude) and health involvement, supported by the observation that age is associated with attitudes and elderly people are more involved in healthy eating ${ }^{(22)}$. Dietary intake of total fish per week is below recommendations in the UK, and approximately in line with recommendations in Norway, Germany and the Netherlands.

The self-reported intake of fish was generally less than half the amount that was estimated based on food balance sheets which assess national levels of production, nonfood use, imports and exports in order to calculate the total food supply in a country. The lower values for self-reported intake could be explained by potential under-reporting of foods that are generally consumed less frequently, such as fish, in a $24 \mathrm{~h}$ recall (as was done in EPIC) or a $4 \mathrm{~d}$ record. Furthermore, the lower values for self-reported intake could also be explained by part-use of the fresh fish product that is purchased, as well as waste during the cooking process. Our comparison of both assessments of fish intake highlights the importance of understanding that studies using FAO apparent consumption levels of total fish may be overestimating actual fish consumption, whereas other dietary assessments may be underestimating how much fish individuals consume.

\section{Fish purchasing and consumption patterns}

In order to obtain more detailed insights into fish purchasing and specific consumption patterns, and therefore into nutrient intakes from fish, we reviewed data available in the UK as an example. For this we used the National Diet and Nutrition Survey (NDNS) data from 2011-2012, which comprised a total of 6828 individuals aged 1.5 years or older who completed at least three days of the food and drink diary ( 3450 adults aged $>19$ years and 3378 children aged 1.5 to 18 years). We assessed the percentage of women and men who reported eating fish by using data obtained from a food and drink diary over a period of four consecutive days (Fig. 2). NDNS had grouped foods into sixty main categories, of which three were fish (white fish; other seafood including shellfish; oily fish). There were 194 foods in these fish groups, which we categorised as white fish (ninety-six foods), oily fish including salmon (fifty-eight foods), salmon (twenty-one foods) and other seafood including shellfish (thirty-two foods). Some foods (e.g. fish pie) contained more than one type of fish. We counted the number of people who had reported consuming any of the categories of white fish, oily fish and salmon. This percentage was lowest in the age group of 11-18 years old; only 39\% of teenage girls and 36\% of teenage boys ate fish. Consistent with patterns in other 
Table 2 Average daily intake of fish and fish products in five European countries

\begin{tabular}{|c|c|c|c|c|c|}
\hline \multirow[b]{2}{*}{ Country } & \multicolumn{2}{|c|}{$\begin{array}{l}\text { Apparent consumption } \\
\text { of total fish* }\end{array}$} & \multirow{2}{*}{$\begin{array}{l}\text { Mean intake of total fish } \\
\text { in EPIC participants } \dagger \\
\text { (g/d; in females/males) }\end{array}$} & \multirow[b]{2}{*}{$\begin{array}{l}\text { Mean intake of total fish } \\
\text { ( } \mathrm{g} / \mathrm{d} \text {; in females/males) }\end{array}$} & \multirow[b]{2}{*}{ Survey methods and source } \\
\hline & $(g / d)$ & $\begin{array}{l}\text { (kg/capita per } \\
\text { year) }\end{array}$ & & & \\
\hline Germany & 39 & 14 & $18 / 20$ & $22 / 28$ & $\begin{array}{l}\text { Mean total fish intake data obtained by } \\
\text { personal diet histories in } 15371 \text { subjects } \\
\text { in } 2005 \text { and } 2006^{(17)}\end{array}$ \\
\hline Netherlands & 65 & 24 & $13 / 18$ & $\begin{array}{l}19 \% / 19 \% \text { ( } \geq \text { twice/week }) \\
71 \% / 71 \% \text { ( } \leq \text { twice/week }) \\
9 \% / 10 \% \text { (never) }\end{array}$ & $\begin{array}{l}\text { Frequency data obtained by two } 24 \mathrm{~h} \text { recalls in } \\
2106 \text { subjects between } 2007 \text { and } 2010^{(18)}\end{array}$ \\
\hline Norway & 146 & 53 & $53 /-$ & $44 / 62$ & $\begin{array}{l}\text { Mean total fish intake data obtained for } \\
\text { participants in Norkost } 3 \text { by two } 24 \mathrm{~h} \\
\text { recalls }^{(19)}\end{array}$ \\
\hline Spain & 118 & 43 & $62 / 92$ & 100 & $\begin{array}{l}\text { Mean total fish intake data obtained by } \\
\text { scanned registration of purchases for } \\
1 \text { week in } 8200 \text { homes in } 2006^{(20)}\end{array}$ \\
\hline UK & 52 & 19 & $29 / 33$ & $22 / 23$ & $\begin{array}{l}\text { NDNS data (mean total fish intake) obtained by } \\
\text { a food and drink diary over four consecutive } \\
\text { days in } 3450 \text { adults aged } 19 \text { years or older } \\
\text { between } 2008 \text { and } 2011^{(21)}\end{array}$ \\
\hline
\end{tabular}

EPIC, European Prospective Investigation into Cancer and Nutrition; NDNS, National Diet and Nutrition Survey.

${ }^{*}$ Apparent consumption based on FAO food balance sheets ${ }^{(16)}$.

† Mean total fish intake data obtained by a $24 \mathrm{~h}$ recall interview in 35955 subjects across Europe between 1992 and 2000(15).
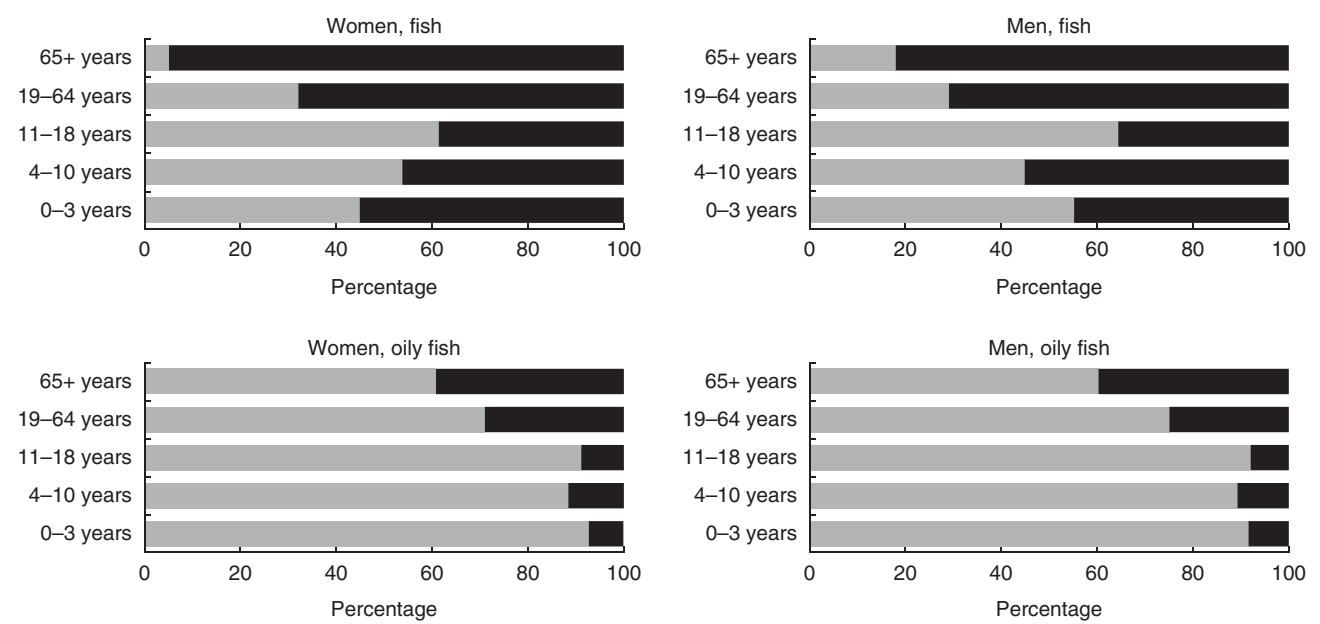

Fig. 2 Percentage of UK women and men eating $(\square)$ or not eating ( $\square$ ) fish or oily fish, per age group, over a period of 4 d (National Diet and Nutrition Survey data 2011-2012)

countries, the percentage of women and men eating fish was highest in the elderly population aged $65+$ years, being $95 \%$ and $82 \%$, respectively. A similar trend was observed for oily fish: the lowest consumption was observed in teenage girls and boys $(9 \%$ and $8 \%$, respectively), whereas the highest consumption was observed in elderly women and men (39\% and 40\%, respectively; Fig. 2). The percentages of 'fish-eaters' may have been an underestimate since food intake was measured for only $4 \mathrm{~d}$. Therefore, anyone who ate fish once weekly had nearly a $50 \%$ chance of this not being recorded on one of the recording days. These data indicate that two to four times as many elderly eat fish than the younger generation.

Despite the UK recommendation to eat two portions of sustainably sourced fish per week (i.e. $40 \mathrm{~g} / \mathrm{d}$ ), of which one should be oily (i.e. $20 \mathrm{~g} / \mathrm{d}$ ), the average level of fish consumption in the UK falls well short of this level. Also, consumption of oily fish is only between $13 \%$ and $42 \%$ of total fish consumption for the youngest and oldest age group, respectively. Importantly, for most age categories, the majority of oily fish consumed was salmon (Table 3).

Considering the fact that salmon consumption is a major contributor to oily fish intake, promoting the consumption of salmon could be an important vehicle to increase total and oily fish intakes in the UK. Purchasing levels of salmon have increased fivefold between 1974 and 2014 (23). We used data from Kantar Worldpanel on about 3000 households in Scotland, who reported food and drink purchases brought into the home between 26 December 2011 and 23 December 2012, to select entries for fresh and frozen fish (17065 entries) in order to assess where customers bought their products. More than $80 \%$ of purchases of fresh salmon products were carried out in supermarkets, with the remainder purchased at discounters, local shops and 
Table 3 Average daily intake of fish (in $\mathrm{g} / \mathrm{d}$ ), including the contribution from composite dishes, by sex and age, in participants of the National Diet and Nutrition Survey 2011-2012

\begin{tabular}{|c|c|c|c|c|c|c|}
\hline & \multicolumn{3}{|c|}{ Women } & \multicolumn{3}{|c|}{ Men } \\
\hline & All fish & Oily fish & Salmon & All fish & Oily fish & Salmon \\
\hline \multicolumn{7}{|l|}{ Age group } \\
\hline 0-3 years & $6 \cdot 6$ & $0 \cdot 8$ & 0.6 & $6 \cdot 3$ & 0.8 & 0.6 \\
\hline $3-10$ years & $9 \cdot 0$ & $2 \cdot 1$ & 1.4 & $11 \cdot 0$ & $2 \cdot 2$ & $1 \cdot 2$ \\
\hline $11-18$ years & 9.5 & $2 \cdot 2$ & 1.7 & 9.3 & 1.5 & $1 \cdot 1$ \\
\hline 19-64 years & $25 \cdot 3$ & 8.7 & 4.6 & 28.5 & $9 \cdot 1$ & $5 \cdot 1$ \\
\hline $65+$ years & 31.1 & $10 \cdot 8$ & 7.0 & $36 \cdot 0$ & $15 \cdot 1$ & 7.5 \\
\hline
\end{tabular}

fishmongers. Currently, most of the salmon purchased in supermarkets is farmed rather than wild (Seafish, UK, personal communication, June 2016). Thus, significant changes in the EPA and DHA content of farmed salmon ${ }^{(7)}$, and the fact that consumers are increasingly buying farmed rather than wild fish, mean that the average intake of LC $n-3$ PUFA among Western populations is most probably lower than before. Despite this decrease in levels of EPA and DHA in farmed salmon over the past years, however, salmon still delivers more LC $n$-3 PUFA than most other fish species and significantly more than other food sources, such as macroalgae-fed lamb or foods fortified with algal products $^{(7)}$.

\section{Effects of fish production regimes on levels of long-chain $n$-3 PUFA, vitamin D, micronutrients and contaminants}

Oily fish are regarded as being high in LC $n$-3 PUFA levels. However, marine fish, including salmon, are inefficient at producing sufficient levels of EPA and DHA in the flesh that would be considered beneficial for human health and so require these fatty acids in their diet ${ }^{(24)}$. Over the past couple of decades, the marine finfish aquaculture industry has invested in using more sustainable, available and cheaper fish feeds containing a higher amount of terrestrial ingredients, mainly derived from oilseed origin, to replace the finite and increasingly expensive marine products of fish oil and fish meal derived from the pelagic fisheries. The introduction of these plant-based feeds has had no major effect on salmon health or growth ${ }^{(25)}$. Nevertheless, the introduction of vegetable oils such as rapeseed oil to replace fish oil in aquafeeds has had a significant effect on the fatty acid composition of farmed salmon flesh, as the fatty acid composition of fish muscle (flesh) reflects that of the diet ${ }^{(26)}$. Rapeseed oil contains $\alpha$-linolenic acid rather than EPA and DHA, which are found almost exclusively in fish oil and other marine sources, Since 2010, levels of oleic acid, linoleic acid and $\alpha$-linolenic acid in farmed salmon doubled from 15\%, 5\% and $2 \%$ in 2010 to $30 \%, 10 \%$ and $5 \%$ in 2015 , respectively, while corresponding levels of EPA and DHA fell by approximately a half ${ }^{(7)}$. This reflects the fact that although production of the global aquaculture feed industry has more than doubled over the period 2000-2012, the level of fish oil used within the same period remained constant ${ }^{(27)}$. Since fish and seafood are the major dietary source of EPA and DHA in the human diet, significant reductions in the content of EPA and DHA in, for example, farmed salmon will result in a significant decrease in the intake of fish fatty acids worldwide. As farmed Atlantic salmon represents an increasingly popular species in the global fish market, largely due to its high market value over low-value freshwater species, this will ultimately affect the intake of fish fatty acids in the human population and thus public health outcomes related to EPA and DHA intake.

Oily fish, including salmon, mackerel, herring and trout, are also the most important dietary source of vitamin D, providing up to $20 \mu \mathrm{g}$ of cholecalciferol (vitamin $\mathrm{D}_{3}$ ) per $100 \mathrm{~g}^{(28)}$. A recent international Vitamin D Standardization Program (VDSP), aiming to improve the quantification of the prevalence of vitamin D deficiency in Europe by standardising existing 25-hydroxyvitamin D (25(OH)D) values from national health/nutrition surveys, found that $13 \%$ of European individuals had serum 25(OH)D concentrations $<30 \mathrm{nmol} / 1$ on average in the year. And according to an alternative suggested definition of vitamin D deficiency $(<50 \mathrm{nmol} / \mathrm{l})$, the prevalence was $40 \%$. That study also found that dark-skinned ethnic subgroups had much higher (3- to 71-fold) prevalence of serum 25(OH)D $<30 \mathrm{nmol} / \mathrm{l}$ than did white populations ${ }^{(29)}$. A nationwide study of predictors of hypovitaminosis D (defined as $25(\mathrm{OH}) \mathrm{D}<40 \mathrm{nmol} / \mathrm{l})$ in British adults aged 45 years found that plasma $25(\mathrm{OH}) \mathrm{D}$ concentrations were higher in participants who either ate oily fish or who took vitamin D supplements compared with those who did not ${ }^{(30)}$. Fish almost exclusively contains the cholecalciferol form of vitamin $\mathrm{D}$, which appears to be the more effective form for both growth of the fish ${ }^{(31)}$ and health of the consumer when given as a large bolus ${ }^{(32,33)}$. Research has highlighted that levels of vitamin $\mathrm{D}$ within and between different fish species can vary ${ }^{(34)}$. One study in the USA also found that farmed salmon contained approximately $25 \%$ of the vitamin D content of wild salmon ${ }^{(35)}$. Moreover, the levels of vitamin D itself have declined in aquaculture fish feeds over the years, at least in Norway, the world's largest producer of farmed Atlantic salmon ${ }^{(26)}$. 
Therefore, consumption of farmed fish may have less impact on improving vitamin D status in consumers compared with wild fish.

Due to the shift in feed ingredients used in formulated fish feeds from fish meal and fish oil to a higher level of plant-derived ingredients, there have been changes in the levels of micronutrient minerals present in the feeds and therefore in the nutrients available to the fish. Between 2000 and 2010, this has resulted in a decline in the levels of iodine, $\mathrm{Zn}$ and $\mathrm{Cu}$ in Norwegian aquafeeds, and presumably in farmed fish, but fish generally do not contribute significantly to average dietary intake levels of these minerals ${ }^{(36)}$. On the other hand, fish, especially those which are marine-derived, are a good source of highly bioavailable dietary Se. However, Se levels can be up to $50 \%$ lower in salmon fillets from fish fed vegetable oil and plant protein compared with fish oil and fish meal, corresponding to a reduction from $43 \%$ to $21 \%$ of the reference nutrient intake for Se for a $130 \mathrm{~g}$ portion ${ }^{(37)}$. Thus, although the reduced Se levels in the terrestrialbased diet satisfied the essential requirement for Se in the salmon, the shift in fish feed composition leads to a significant reduction in the supply of this essential micronutrient to the human diet. Se, in the form of selenocysteine, is incorporated into a range of enzymes that are important to human health, such as glutathione peroxidase, which plays an important role in protecting cell membranes from free-radical-induced oxidation. Se also plays a key role in the functioning of the immune system and in thyroid hormone metabolism ${ }^{(38)}$. The recognition of the importance of Se in health has led to considerable concern about its falling intakes in the UK and Northern Europe over the last few decades, thought largely due to the reduction in the import and consumption of high-Se wheat from North America and Canada ${ }^{(39)}$. Because fish is an important dietary source of Se, halving the Se content due to changes in fish feeding regimes could have significant consequences for overall Se intake within consumers.

Although the decreases in LC $n-3$ PUFA, vitamin D and Se are of concern, a potential benefit of the changes in fish feed composition is the concomitant decrease in levels of contaminants in fish. Indeed, as changes in fish feed production processes have resulted in the partial replacement of fish oil and fish protein with plant proteins and vegetable oils, the concentration of dioxins/dioxin-like polychlorinated biphenyls and $\mathrm{Hg}$ has decreased to $30 \%$ and $50 \%$, respectively, compared with levels in 2006, in farmed Atlantic salmon ${ }^{(19,36,40)}$. However, the increased inclusion of vegetable oils has led to new types of contaminants in fish, including pesticide endosulfan, polyaromatic hydrocarbons and mycotoxins. Nevertheless, the concentrations of contaminants in farmed fish, taking into account current consumption patterns, represent a negligible risk to $\mathrm{CHD}$ and cancer risk ${ }^{(1,19)}$. The benefits of eating fish are believed to outweigh the risks presented by current levels of contaminants and therefore, in Norway, the recommended upper limit for intake of fatty fish in pregnant women was recently lifted ${ }^{(19)}$.

\section{Conclusion}

In conclusion, fish remains an important dietary source not only of LC $n$-3 PUFA, but also of vitamin $\mathrm{D}$ and other micronutrients such as Se. This is important, as increasing evidence suggests that the beneficial effects of fish consumption may be explained by the interplay of a wider range of nutrients in this food, rather than the content of LC $n$-3 PUFA alone ${ }^{(41-43)}$. In the last decade, the actual content of EPA and DHA in farmed salmon has nearly halved due to the substitution of the fish meal and fish oil in fish feeds to more sustainable alternatives of terrestrial origin. The role of aquaculture in global fish production has increased significantly since the 1990s, and currently just under half of all fish we eat around the world is farmed $^{(16)}$. Farmed salmon is becoming increasingly important as a source of EPA and DHA in many Western countries and as farmed finfish species may have a higher oil and LC $n$-3 PUFA content than the same or other species from the wild, they remain an excellent means to achieve substantial intake of LC $n$-3 PUFA and other ingredients ${ }^{(44)}$. However, our intake not only of $n$-3 fatty acids, but also of vitamin $\mathrm{D}$ and Se, from fish generally, and from salmon specifically, is likely to decrease in the next years, unless other potential sources of EPA and DHA, such as microalgae and GM oilseed crops that have been engineered to synthesise EPA and DHA, are applied for fish feed ${ }^{(7)}$. If the current trend of decreasing levels of EPA, DHA, vitamin D and micronutrients in farmed salmon continues, we may well need to eat more fish to provide similar health benefits than those described previously ${ }^{(8)}$. Future recommendations for fish intake, which are currently based on cohort studies that were performed one to two decades ago, when EPA and DHA intake from fish was probably significantly higher than it is now, will need to take account of this.

\section{Acknowledgements}

Financial support: The research of B.d.R., A.A.S. and G.H. is supported by the Scottish Government's Rural and Environment Science and Analytical Services Division (RESAS). M.S. is funded by the University of Stirling. The funders had no role in the design, analysis or writing of this article. Conflict of interest: None to report. Authorship: The research question was formulated by B.d.R. and I.A.B. B.d.R. and I.A.B. performed a critical assessment of national dietary guidelines in a selection of European countries and the USA. G.W.H. performed analysis of data from the NDNS database. All authors contributed to the writing of the manuscript. Ethics of human subject participation: Not applicable. 


\section{References}

1. Food and Agriculture Organization of the United Nations \& World Health Organization (2010) Joint FAO/WHO Expert Consultation on the Risks and Benefits of Fish Consumption. FAO Fisheries and Aquaculture Report no. 978. Rome: FAO.

2. High Level Panel of Experts on Food Security and Nutrition of the Committee on World Food Security (2014) Sustainable Fisheries and Aquaculture for Food Security and Nutrition. Rome: HPLE.

3. Food and Agriculture Organization of the United Nations (2016) The State of World Fisheries and Aquaculture. Contributing to Food Security and Nutrition for All. Rome: FAO.

4. World Bank (2013) Fish to 2030: Prospects for Fisheries and Aquaculture, World Bank Report no. 83177. Washington, DC: World Bank.

5. Naylor RL, Hardy RW, Bureau DP et al. (2009) Feeding aquaculture in an era of finite resources. Proc Natl Acad Sci U S A 106, 15103-15110.

6. Ytrestoyl T, Aas TS \& Asgard T (2015) Utilisation of feed resources in production of Atlantic salmon (Salmo salar) in Norway. Aquaculture 448, 365-374.

7. Sprague M, Dick JR \& Tocher DR (2016) Impact of sustainable feeds on omega-3 long-chain fatty acid levels in farmed Atlantic salmon, 2006-2015. Sci Rep 6, 21892.

8. Zheng J, Huang T, Yu Y et al. (2012) Fish consumption and CHD mortality: an updated meta-analysis of seventeen cohort studies. Public Health Nutr 15, 725-737.

9. Xun P, Qin B, Song Y et al. (2012) Fish consumption and risk of stroke and its subtypes: accumulative evidence from a meta-analysis of prospective cohort studies. Eur J Clin Nutr 66, 1199-1207.

10. Scientific Advisory Committee on Nutrition (2004) Advice on Fish Consumption: Benefits and Risks. Norwich: TSO.

11. Health Council of the Netherlands (2015) Dutch Dietary Guidelines 2015. Report no. 2015/24. The Hague: Health Council of the Netherlands.

12. Health Council of the Netherlands (2011) Guidelines for a Healthy Diet: The Ecological Perspective. Publication no. 2011/08E. The Hague: Health Council of the Netherlands.

13. Wolfram G, Bechthold A, Boeing H et al. (2015) Evidencebased guideline of the German Nutrition Society: fat intake and prevention of selected nutrition-related diseases. Ann Nutr Metab 67, 141-204.

14. World Health Organization \& Food and Agriculture Organization of the United Nations (1998) Preparation and Use of Food-Based Dietary Guidelines. Joint FAO/WHO Consultation. WHO Technical Report Series no. 880. Geneva: WHO

15. Welch AA, Lund E, Amiano P et al. (2002) Variability of fish consumption within the 10 European countries participating in the European Investigation into Cancer and Nutrition (EPIC) study. Public Health Nutr 5, 1273-1285.

16. Food and Agriculture Organization of the United Nations (2014) The State of World Fisheries and Aquaculture: Opportunities and Challenges. Rome: FAO.

17. Heuer T, Krems C, Moon K et al. (2015) Food consumption of adults in Germany: results of the German National Nutrition Survey II based on diet history interviews. $\mathrm{Br} \mathrm{J}$ Nutr 113, 1603-1614.

18. National Institute for Public Health and the Environment (2016) Dutch National Food Consumption Survey 20072010. Bilthoven: RIVM.

19. Norwegian Scientific Committee for Food Safety (2014) Benefit-Risk Assessment of Fish and Fish Products in the Norwegian Diet - An Update. Opinion of the Scientific Steering Committee of the Norwegian Scientific Committee for Food Safety. VKM Report 2014:15. Oslo: VKM.
20. Varela-Moreiras G, Avila JM, Cuadrado C et al. (2010) Evaluation of food consumption and dietary patterns in Spain by the Food Consumption Survey: updated information. Eur J Clin Nutr 64, Suppl. 3, S37-S43.

21. Public Health England (2014) National Diet and Nutrition Survey: Results from Years 1-4 (combined) of the Rolling Programme (2008/2009-2011/12). London: Public Health England.

22. Olsen SO (2003) Understanding the relationship between age and seafood consumption: the mediating role of attitude, health involvement and convenience. Food Qual Prefer 14, 199-209.

23. Office for National Statistics (2015) Living Costs and Food Survey 2014. London: ONS.

24. Tocher DR (2015) Omega-3 long chain polyunsaturated fatty acids and aquaculture in perspective. Aquaculture 449, 94-107.

25. Bell JG, Henderson RJ, Tocher DR et al. (2004) Replacement of dietary fish oil with increasing levels of linseed oil: modification of flesh fatty acid compositions in Atlantic salmon (Salmo salar) using a fish oil finishing diet. Lipids 39, 223-232.

26. Sargent JR, Tocher DR \& Bell JG (2002) The lipids. In Fish Nutrition, 3rd ed., pp. 181-257 [JE Halver and RW Hardy, editors]. San Diego, CA: Academic Press.

27. Shepherd CJ \& Bachis E (2014) Changing supply and demand for fish oil. Aquacult Econ Manage 18, 395-416.

28. Institute of Medicine (2011) Dietary Reference Intakes for Calcium and Vitamin D. Washington, DC: National Academies Press.

29. Cashman KD, Dowling KG, Skrabakova Z et al. (2016) Vitamin D deficiency in Europe: pandemic? Am J Clin Nutr 103, 1033-1044.

30. Hypponen E \& Power C (2007) Hypovitaminosis D in British adults at age $45 \mathrm{y}$ : nationwide cohort study of dietary and lifestyle predictors. Am J Clin Nutr 85, 860-868.

31. Barnett BJ, Cho CY \& Slinger SJ (1982) Relative biopotency of dietary ergocalciferol and cholecalciferol and the role of and requirement for vitamin D in rainbow trout (Salmo gairdneri). J Nutr 112, 2011-2019.

32. Trang HM, Cole DE, Rubin LA et al. (1998) Evidence that vitamin $\mathrm{D}_{3}$ increases serum 25-hydroxyvitamin $\mathrm{D}$ more efficiently than does vitamin $\mathrm{D}_{2}$. Am J Clin Nutr 68, 854-858.

33. Tripkovic L, Lambert H, Hart K et al. (2012) Comparison of vitamin $\mathrm{D}_{2}$ and vitamin $\mathrm{D}_{3}$ supplementation in raising serum 25-hydroxyvitamin D status: a systematic review and metaanalysis. Am J Clin Nutr 95, 1357-1364.

34. Mattila P, Piironen V, Haapala R et al. (1997) Possible factors responsible for the high variation in the cholecalciferol contents of fish. J Agric Food Chem 45, 3891-3896.

35. Lu Z, Chen TC, Zhang A et al. (2007) An evaluation of the vitamin $D_{3}$ content in fish: is the vitamin $D$ content adequate to satisfy the dietary requirement for vitamin D? J Steroid Biochem Mol Biol 103, 642-644.

36. Sissener NH, Julshamn K, Espe M et al. (2012) Surveillance of selected nutrients, additives and undesirables in commercial Norwegian fish feeds in the years 2000-2010. Aquacult Nutr 19, 555-572.

37. Betancor MB, Dam TM, Walton J et al. (2016) Modulation of selenium tissue distribution and selenoprotein expression in Atlantic salmon (Salmo salar L.) fed diets with graded levels of plant ingredients. Br J Nutr 115, 1325-1338.

38. Arthur JR (1991) The role of selenium in thyroid hormone metabolism. Can J Physiol Pharmacol 69, 1648-1652.

39. Barclay MN \& MacPherson A (1992) Selenium content of wheat for bread making in Scotland and the relationship between glutathione peroxidase (EC 1.11.1.9) levels in whole blood and bread consumption. Br J Nutr 68, 261-270. 
40. Bell JG, Dick JR, Strachan F et al. (2012) Complete replacement of fish oil affects dioxin, dioxin-like polychlorinated biphenyls (PCBs) and polybrominated diphenyl ethers (PBDEs) in 3 Atlantic salmon (Salmo salar) families differing in adiposity. Aquaculture 324-325, 118-126.

41. Chowdhury R, Stevens S, Gorman D et al. (2012) Association between fish consumption, long chain omega 3 fatty acids, and risk of cerebrovascular disease: systematic review and meta-analysis. BMJ 345, e6698.

42. Rylander C, Sandanger TM, Engeset D et al. (2014) Consumption of lean fish reduces the risk of type 2 diabetes mellitus: a prospective population based cohort study of Norwegian women. PLoS One 9, e89845.

43. Aadland EK, Lavigne C, Graff IE et al. (2015) Leanseafood intake reduces cardiovascular lipid risk factors in healthy subjects: results from a randomized controlled trial with a crossover design. Am J Clin Nutr 102, 582-592.

44. Nichols PD, Glencross B, Petrie JR et al. (2014) Readily available sources of long-chain omega-3 oils: is farmed Australian seafood a better source of the good oil than wildcaught seafood? Nutrients 6, 1063-1079. 